\title{
Variation of pH Dependent Acidity and Total Potential Acidity as Influenced by Land Uses and Soil Depths in Lateritic Belt of West Bengal
}

\author{
Jhutan Debnath*, Prodipto Sow and Manik Chandra Kundu \\ Department of Soil Science and Agricultural Chemistry, Institute of Agriculture (Palli Siksha \\ Bhavana), Visva-Bharati University, Sriniketan, West Bengal, India \\ *Corresponding author
}

\section{A B S T R A C T}

\section{Keywords}

Total potential acidity, Land uses, $\mathrm{pH}$ dependent acidity, Bulk density

\section{Article Info}

\section{Accepted:}

12 December 2020

Available Online:

10 January 2021
Soil acidity is also the major problem of the red and lateritic soils. Acidification causes the loss of base cations and increases aluminium saturation and as a result, decrease in crop yields. Among the different nature of soil acidity, $\mathrm{pH}$ dependent acidity (pHDA) and total potential acidity (TPA) are very important in relation to nutrient supplying capacity of the soil. To study depth-wise and land use-wise variation of $\mathrm{pH}$ dependent acidity (pHDA) and total potential acidity (TPA) and its relationship with soil properties, fifty-four representative soil samples were collected from three depths (viz., $0-20 \mathrm{~cm}, 20-40 \mathrm{~cm}$ and $40-60 \mathrm{~cm}$ ) from 6 various land uses viz., forest land, cultivated rice land, cultivated ricepotato land, orchard land, pasture land and fallow land of Birbhum district of lateritic zone of West Bengal. The soil samples were analyzed for pHDA and TPA and soil properties like $\mathrm{pH}, \mathrm{EC}$, organic $\mathrm{C}$, bulk density, particle density, available $\mathrm{N}, \mathrm{P}_{2} \mathrm{O}_{5}$ and $\mathrm{K}_{2} \mathrm{O}$ using standard methodology. It was observed that there was significant depth-wise and land usewise variation of pHDA and TPA. In all the land uses, pHDA and TPA was decreased with depth. The mean pHDA irrespective of soil depths was highest in cultivated rice-potato land and lowest in pasture land. The mean TPA irrespective of soil depths was highest in cultivated rice-potato land and lowest in pasture land. TPA and pHDA were significantly positively and negatively correlated with $\mathrm{OC}$ and $\mathrm{BD}$ of soil respectively.

\section{Introduction}

Soil acidity is a major constraint to cropping globally. Acid soils are very poor in fertility status, and plant growth is hampered to a large extent in strongly to moderately acidic soils and these soils lower the crop yield to a great extent. It also reduce growth and survival of important soil microbes (Bhat et al., 2010; Kundu, 2017). Parfitt et al., (1997) reported that decomposition of organic matter and transformation of $\mathrm{N}$ and $\mathrm{S}$ were reported to contribute to soil acidity. The acidity nature of the soil is mainly due to the leaching of the bases due to the existing high rainfall conditions and also due to presence of acidic parent materials (Shivaprasad et al., 1998; Kundu, 2017). Soil acidification is caused by 
a number of factors including acidic precipitation and the deposition from the atmosphere of acidifying gases or particles, such as sulphur dioxide, ammonia and nitric acid. The most important causes of soil acidification on agricultural landare the application of ammonium-based fertilizers, urea, elemental $\mathrm{S}$ fertilizer. Acidification causes the loss of base cations, an increase in aluminium saturation and a decline in crop yields; severe acidification can cause nonreversible clay mineral dissolution and a reduction in cation exchange capacity, accompanied by structural deterioration (Brady and Weil, 2008). Soil acidity is also the major problem of the red and lateritic soils representing the Alfisols, Entisols and Inceptisols of West Bengal, India, leading to severe toxicity of iron, aluminum and manganese, accompanied by deficiency of phosphorus and low microbial activity causing poor growth of crops (Mandal and Mandal 1997; Kundu, 2017; Bhat et al., 2017). The proportion of different forms of acidities in such acid soils determines their nutrient holding capacities.

\section{Materials and Methods}

Representative soil samples from three depths (viz., 0-20 cm, 20-40 cm and 40-60 cm) were collected from six dominant land uses (viz., forest land, pasture land, orchard land, cultivated rice land, cultivated rice-potato land and fallow land) of Birbhum district of lateriticzone of West Bengal in the year 2017. Total 54 [6(land use types) $\mathrm{X} \quad 3$ (representative fields) X 3 (depths) = 54]soil samples were collected which were processed by air-drying, mixing and sieving by $2 \mathrm{~mm}$ sieve for the analysis. Separate core samples from each soil depths were collected for determination of bulk density. Different soil properties like $\mathrm{pH}$ by glass electrode $\mathrm{pH}$ meter (1:2.5::soil:water; Jackson, 1973), electrical conductivity (1:2::soil:water;
Jackson, 1973), oxidizable organic C (Walkley and Black,1934), sand, slit and clay content (hydrometer method),bulk density (BD) by core method (Black and Hartge, 1986), particle density (PD) by pycnometer method (Black, 1965), available nitrogen by alkaline $\mathrm{KMnO}_{4}$ method (Subbiah and Asija, 1956), available phosphorus by Bray's method (Bray and Kurtz, 1945), available potassium by using neutral normal ammonium acetate extractant method (Hanway and Heidel, 1952). Total potential acidity was determined by extracting the soils with barium chloride-triethanol amine (BaCl2-TEA) (buffered at $\mathrm{pH}$ 8.2) by Peech's method (Peech et al., 1962). The $\mathrm{pH}$ dependant acidity was computed as the difference between total potential acidity and exchange acidity.

\section{Data analysis}

The analysis of variance (ANOVA) of the effects of various land use types and soil depths on $\mathrm{pH}$ dependent acidity and total potential acidity were tested by the procedure as described by Gomez and Gomez (1984). Simple Pearson's correlation analysis was done to estimate the relationship of $\mathrm{pH}$ dependent acidity and total potential acidity with soil properties using SPSS software (version 20).

\section{Results and Discussion}

\section{Effects of land use types and soil depthson pH dependent acidity (pHDA)of soil}

There was significant depth-wise variation inpH dependent acidity (pHDA) of soil in various land use types (Table 1, Fig.1) and land use type-wise variations in $\mathrm{pH}$ dependent acidity (pHDA) of soil in various soil depths studied (Table 2, Fig. 2).In all the land use types the highest $\mathrm{pH}$ dependent acidity (pHDA) was recorded in surface $0-20 \mathrm{~cm}$ soil 
depth and the lowest value of $\mathrm{pH}$ dependent acidity (pHDA) was recorded in $40-60 \mathrm{~cm}$ soil depth. In surface soil of $0-20 \mathrm{~cm}$ depth highest $\mathrm{pH}$ dependent acidity (pHDA) was recorded in cultivated rice-potato land [4.44 cmol $\left.\left(\mathrm{p}^{+}\right) \mathrm{kg}^{-1}\right]$ and lowest $\mathrm{pH}$ dependent acidity (pHDA) was observed in pasture land [2.27 $\left.\mathrm{cmol}\left(\mathrm{p}^{+}\right) \mathrm{kg}^{-1}\right]$. It was again observed that $\mathrm{pH}$ dependent acidity (pHDA) of soil of $20-40 \mathrm{~cm}$ depth of cultivated rice land and fallow land was statistically at par. In this 20$40 \mathrm{~cm}$ depth of soil, highest $\mathrm{pH}$ dependent acidity (pHDA)was recorded in cultivated rice-potato land $\left[3.88 \mathrm{cmol}\left(\mathrm{p}^{+}\right) \mathrm{kg}^{-1}\right]$ and lowest $\mathrm{pH}$ dependent acidity (pHDA) was observed in pasture land $\left[1.93 \mathrm{cmol}\left(\mathrm{p}^{+}\right) \mathrm{kg}^{-1}\right]$. $\mathrm{pH}$ dependent acidity (pHDA) of soil of 40-60 $\mathrm{cm}$ depth of cultivated rice land and fallow land was statistically at par. In this $40-60 \mathrm{~cm}$ depth of soil, highest $\mathrm{pH}$ dependent acidity (pHDA)was recorded in cultivated rice-potato land $\left[2.65 \mathrm{cmol}\left(\mathrm{p}^{+}\right) \mathrm{kg}^{-1}\right]$ which was, however, statistically at par with forest land [1.39 $\left.\mathrm{cmol}\left(\mathrm{p}^{+}\right) \mathrm{kg}^{-1}\right]$ and lowest total acidity was observed in pasture land $\left[1.82 \mathrm{cmol}\left(\mathrm{p}^{+}\right)\right.$ $\left.\mathrm{kg}^{-1}\right]$.

Considering the main effects of land use types (irrespective of soil depths) it was observed that mean $\mathrm{pH}$ dependent acidity (pHDA) of cultivated rice-potato land was recorded highest $\left[3.66 \mathrm{cmol}\left(\mathrm{p}^{+}\right) \mathrm{kg}^{-1}\right]$ and that of pasture land recorded lowest $\left[2.00 \mathrm{cmol}\left(\mathrm{p}^{+}\right)\right.$ $\mathrm{kg}^{-1}$ ] (Table 1). Contribution made by $\mathrm{pH}$ dependent acidity may be due to $\mathrm{pH}$ dependent charges associated with increased $\mathrm{Fe}$ and $\mathrm{Al}$ oxides and organic matter (Dhananjaya et al., 2009).

Considering the effects of soil depths (irrespective of land use types) it was observed that the mean $\mathrm{pH}$ dependent acidity (pHDA) was highest in surface $0-20 \mathrm{~cm}$ soil depth [2.91 $\left.\mathrm{cmol}\left(\mathrm{p}^{+}\right) \mathrm{kg}^{-1}\right]$ and lowest in 40$60 \mathrm{~cm}$ soil depth [2.07 cmol $\left.\left(\mathrm{p}^{+}\right) \mathrm{kg}^{-1}\right]$. In general, it was observed that the $\mathrm{pH}$ dependent acidity (pHDA) was decreased with increase in soil depth (Table 2). The main reason behind it may be the accumulation of basic cations $(\mathrm{Ca}$ and $\mathrm{Mg}$ ions) in the sub-surface horizon and at the same time removal of basic cations by plant uptake in the surface soil depths increases $\mathrm{pH}$ dependent acidity (pHDA) of surface soil.

While studying the interaction effect of land use types and soil depth on $\mathrm{pH}$ dependent acidity (pHDA), it was observed that the highest $\left[4.44 \mathrm{cmol}\left(\mathrm{p}^{+}\right) \mathrm{kg}^{-1}\right] \mathrm{pH}$ dependent acidity (pHDA)was recorded at the surface 0$20 \mathrm{~cm}$ soil depth of the cultivated rice-potato land, and the lowest $\left[1.82 \mathrm{cmol}\left(\mathrm{p}^{+}\right) \mathrm{kg}^{-1}\right]$ was obtained at $40-60 \mathrm{~cm}$ soil depth of the fallow land which was statistically par with 40-60 $\mathrm{cm}$ depth of cultivated rice land $[2.06 \mathrm{cmol}$ $\left.\left(\mathrm{p}^{+}\right) \mathrm{kg}^{-1}\right]$ and fallow land $\left[1.99 \mathrm{cmol}\left(\mathrm{p}^{+}\right) \mathrm{kg}^{-}\right.$ ${ }^{1}$ ] and at the soil depth of 20-40 $\mathrm{cm}$ of pasture land [1.93 $\left.\mathrm{cmol}\left(\mathrm{p}^{+}\right) \mathrm{kg}^{-1}\right]$ (Table 3). With the exception of few treatment combinations of interaction effects of land use types and soil depth on $\mathrm{pH}$ dependent acidity (pHDA), most of the treatment combinations were statistically at par $(\mathrm{P} \leq 0.05)$ with each other (Table 3).

\section{Effects of land use types and soil depths on total potential acidity (TPA)of soil}

There was significant depth-wise variation in total potential acidity (TPA)of soil in various land use types (Table 4, Fig. 3)and land use type-wise variations in total potential acidity (TPA) of soil in various soil depths studied (Table 5, Fig. 4). In all the land use types the highest total potential acidity (TPA)was recorded in surface $0-20 \mathrm{~cm}$ soil depth and the lowest value of total potential acidity (TPA)was recorded in 40-60 cm soil depth.

In surface soil of $0-20 \mathrm{~cm}$ depth highest total potential acidity (TPA) was recorded in cultivated rice-potato land $\left[5.02 \mathrm{cmol}\left(\mathrm{p}^{+}\right)\right.$ 
$\mathrm{kg}^{-1}$ ] and lowest total potential acidity (TPA)was observed in pasture land [2.55 cmol $\left.\left(\mathrm{p}^{+}\right) \mathrm{kg}^{-1}\right]$. It was again observed that total potential acidity (TPA)of soil of 20-40 $\mathrm{cm}$ depth of cultivated rice land and fallow land was statistically at par. In this $20-40 \mathrm{~cm}$ depth of soil, highest total potential acidity (TPA)was recorded in cultivated rice-potato land [4.33 $\mathrm{cmol}\left(\mathrm{p}^{+}\right) \mathrm{kg}^{-1}$ ] and lowest total potential acidity was observed in pasture land $\left[2.18 \mathrm{cmol}\left(\mathrm{p}^{+}\right) \mathrm{kg}^{-1}\right]$. Total potential acidity (TPA)of soil of 40-60 $\mathrm{cm}$ depth of cultivated rice land and fallow land was statistically at par. In this $40-60 \mathrm{~cm}$ depth of soil, highest total potential acidity was recorded in cultivated rice-potato land $\left[2.98 \mathrm{cmol}\left(\mathrm{p}^{+}\right)\right.$ $\left.\mathrm{kg}^{-1}\right]$ and lowest total potential acidity was observed in pasture land $\left[2.05 \mathrm{cmol}\left(\mathrm{p}^{+}\right) \mathrm{kg}^{-1}\right]$.

Considering the main effects of land use types (irrespective of soil depths) it was observed that mean total potential acidity of cultivated rice-potato land was recorded highest [4.11 cmol $\left.\left(\mathrm{p}^{+}\right) \mathrm{kg}^{-1}\right]$ and that of pasture land recorded lowest $\left[2.26 \mathrm{cmol}\left(\mathrm{p}^{+}\right) \mathrm{kg}^{-1}\right]$ (Table 4). Thus, land use changes from forest to crop land, resulted in increase in total potential acidity of the study area. Such highest value of total potential acidity under the cultivated rice-potato land may be either due to the depletion of basic cations in crop harvest and drainage to streams in runoff generated from accelerated erosions or due to its highest microbial oxidation that produces organic acids, which provide $\mathrm{H}^{+}$ions to the soil solution and thereby lowers the soil $\mathrm{pH}$.

Considering the effects of soil depths (irrespective of land use types) it was observed that the mean total potential acidity was highest in surface $0-20 \mathrm{~cm}$ soil depth [3.29 $\mathrm{cmol}\left(\mathrm{p}^{+}\right) \mathrm{kg}^{-1}$ ] and lowest in $40-60 \mathrm{~cm}$ soil depth $\left[2.32 \mathrm{cmol}\left(\mathrm{p}^{+}\right) \mathrm{kg}^{-1}\right]$. In general, it was observed that the total potential acidity (TPA) was decreased with increase in soil depth (Table 5). The main reason behind it may be the accumulation of basic cations $(\mathrm{Ca}$ and $\mathrm{Mg}$ ions) in the below surface horizon and at the same time removal of basic cations by plant uptake in the surface soil depths increases total potential acidity of surface soil.

While studying the interaction effect of land use types and soil depth on total potential acidity, it was observed that the highest [5.02 cmol $\left.\left(\mathrm{p}^{+}\right) \mathrm{kg}^{-1}\right]$ total potential acidity (TPA) was recorded at the surface $0-20 \mathrm{~cm}$ soil depth of the cultivated rice-potato land, and the lowest $\left[2.05 \mathrm{cmol}\left(\mathrm{p}^{+}\right) \mathrm{kg}^{-1}\right]$ was obtained at 40-60 cm soil depth of the fallow land which was statistically par with the depth of soil at $20-40 \mathrm{~cm}$ of the pasture land [2.18 cmol $\left.\left(\mathrm{p}^{+}\right) \mathrm{kg}^{-1}\right]$, (Table 6). With the exception of few treatment combinations of interaction effects of land use types and soil depth on total potential acidity (TPA), most of the treatment combinations were statistically at $\operatorname{par}(\mathrm{P} \leq 0.05)$ with each other (Table 6$)$.

\section{Correlation of pH dependent acidity and total potential acidity with soil properties}

Simple Pearson's correlation studies between $\mathrm{pH}$ dependent acidity and total potential acidity with soil properties showed that soil $\mathrm{pH}$ of the land use types was significantly and negatively correlated with pHDA $(\mathrm{r}=-0.820$, $\mathrm{P} \leq 0.01)$, TPA $(\mathrm{r}=-0.826, \mathrm{P} \leq 0.01)$. Kumar et al., (1995) reported similar significant negative correlation between soil $\mathrm{pH}$ with $\mathrm{pH}$ dependent acidity and total potential acidity. Correlation coefficient study also showed that soil OC of the land use types was significantly, positively and highly correlated with pHDA $(\mathrm{r}=0.552, \mathrm{P} \leq 0.01)$, TPA $(\mathrm{r}=$ $0.526, \mathrm{P} \leq 0.01)$ and $\mathrm{PD}$ of soil of the land use types was significantly and positively correlated with $\mathrm{pHDA}(\mathrm{r}=0.323, \mathrm{P} \leq 0.05)$ and TPA $(\mathrm{r}=0.322, \mathrm{P} \leq 0.05)$. Badole et al., (2015) also reported the significant positive correlation between organic $\mathrm{C}$ with $\mathrm{pH}$ dependent acidity and total potential acidityin acidic soil of West Bengal. 
In conclusion, $\mathrm{pH}$ dependent acidity (pHDA) and total potential acidity (TPA) was varied significantly along depth and land uses and its value was decreased with depth. The mean pHDA irrespective of soil depths was highest in cultivated rice-potato land and lowest in pasture land. The mean pHDA irrespective of land use types was highest in surface $0-20 \mathrm{~cm}$ soil depth and lowest in 40-60 cm soil depth. Interaction effect of land use types and soil depth showed that the highest pHDA was recorded at the surface $0-20 \mathrm{~cm}$ soil depth of the cultivated rice-potato land, and the lowest was obtained at 40-60 $\mathrm{cm}$ soil depth of the fallow land which was statistically par with $40-60 \mathrm{~cm}$ depth of cultivated rice land and fallow land and at the soil depth of $20-40 \mathrm{~cm}$ of pasture land. The mean TPA irrespective of soil depths was highest in cultivated ricepotato land and lowest in pasture land. The mean TPA irrespective of land use types was highest in surface $0-20 \mathrm{~cm}$ soil depth and lowest in 40-60 $\mathrm{cm}$ soil depth. Interaction effect of land use types and soil depth showed that the highest TPA was recorded at the surface $0-20 \mathrm{~cm}$ soil depth of the cultivated rice-potato land and the lowest was obtained at $40-60 \mathrm{~cm}$ soil depth of the fallow land which was statistically par with the depth of soil at $20-40 \mathrm{~cm}$ of the pasture land. Again, pHDA and TPA were significantly positively and negatively correlated with $\mathrm{OC}$ and $\mathrm{BD}$ of soil respectively.

Table.1 Depth-wise variations in mean pH dependent acidity (pHDA) of soil of different land use types and main effects of land use types (irrespective of soil depth) on pHDA

\begin{tabular}{|c|c|c|c|c|c|c|}
\hline \multirow[t]{2}{*}{ Depth of soil } & \multicolumn{6}{|c|}{ pHDA $\left[\mathrm{cmol}\left(\mathrm{p}^{+}\right) \mathrm{kg}^{-1}\right]$ of soil at various land use types } \\
\hline & $\begin{array}{c}\text { Forest } \\
\text { land }\end{array}$ & $\begin{array}{l}\text { Orchard } \\
\text { land }\end{array}$ & $\begin{array}{l}\text { Pasture } \\
\text { land }\end{array}$ & $\begin{array}{l}\text { Cultivated } \\
\text { land (Rice) }\end{array}$ & $\begin{array}{l}\text { Cultivated land } \\
\text { (Rice-potato) }\end{array}$ & $\begin{array}{l}\text { Fallow } \\
\text { land }\end{array}$ \\
\hline \multicolumn{7}{|c|}{ Depth-wise variations in mean pHDAof soil of different land use types } \\
\hline $0-20 \mathrm{~cm}$ & $3.36^{\mathrm{a}}$ & $3.24^{\mathrm{a}}$ & $2.27^{\mathrm{a}}$ & $2.53^{\mathrm{a}}$ & $4.44^{\mathrm{a}}$ & $2.61^{\mathrm{a}}$ \\
\hline $20-40 \mathrm{~cm}$ & $2.86^{\mathrm{b}}$ & $2.51^{b}$ & $1.93^{\mathrm{b}}$ & $2.17^{\mathrm{b}}$ & $3.88^{b}$ & $2.31^{\mathrm{b}}$ \\
\hline $40-60 \mathrm{~cm}$ & $2.40^{\mathrm{c}}$ & $2.20^{c}$ & $1.82^{\mathrm{c}}$ & $2.06^{\mathrm{b}}$ & $2.65^{\mathrm{c}}$ & $1.99^{c}$ \\
\hline$S E(m)$ & 0.05 & 0.06 & 0.02 & 0.04 & 0.11 & 0.05 \\
\hline$S E(D)$ & 0.07 & 0.08 & 0.02 & 0.06 & 0.15 & 0.07 \\
\hline$L S D(0.05)$ & 0.16 & 0.20 & 0.06 & 0.15 & 0.36 & 0.18 \\
\hline p-value & $0.000 * *$ & $0.000 * *$ & $0.000 * *$ & $0.001 * *$ & $0.000 * *$ & $0.001 * *$ \\
\hline \multicolumn{7}{|c|}{$\begin{array}{l}\text { Mean value within the same column follow by same letter are not significantly different from each other at } \\
\text { p }<0.05 \text {; * Significant at } P \leq 0.05 ; * * \text { Significant at } P \leq 0.01 \text {, NS non significant }\end{array}$} \\
\hline \multicolumn{7}{|c|}{ Main effects of land use types (irrespective of soil depth) on pHDAof soil } \\
\hline $\begin{array}{l}\text { Mean } \\
\text { pHDA }\end{array}$ & $2.87^{\mathrm{b}}$ & $2.65^{\mathrm{c}}$ & $2.00^{\mathrm{e}}$ & $2.25^{\mathrm{d}}$ & $3.66^{\mathrm{a}}$ & $2.30^{\mathrm{d}}$ \\
\hline$S E(m)$ & \multicolumn{6}{|c|}{0.035} \\
\hline$S E(D)$ & \multicolumn{6}{|c|}{0.049} \\
\hline$L S D(0.05)$ & \multicolumn{6}{|c|}{0.099} \\
\hline p-value & \multicolumn{6}{|c|}{$0.000 * *$} \\
\hline
\end{tabular}


Table.2 Land use types-wise variations in mean $\mathrm{pH}$ dependent acidity (pHDA) of soil in different depth and main effects of depth of soil (irrespective of land use types) on pHDA

\begin{tabular}{|c|c|c|c|}
\hline \multirow[t]{2}{*}{ Land use types } & \multicolumn{3}{|c|}{ pHDA $\left[\mathrm{cmol}\left(\mathrm{p}^{+}\right) \mathrm{kg}^{-1}\right]$ at various soil depth } \\
\hline & $0-20 \mathrm{~cm}$ & $20-40 \mathrm{~cm}$ & $40-60 \mathrm{~cm}$ \\
\hline \multicolumn{4}{|c|}{ Land use-wise variations in mean pHDA of soil in different depth } \\
\hline Forest land & $3.36^{\mathrm{b}}$ & $2.86^{\mathrm{b}}$ & $2.40^{\mathrm{b}}$ \\
\hline Orchard land & $3.24^{\mathrm{b}}$ & $2.51^{\mathrm{c}}$ & $2.20^{c}$ \\
\hline Pasture land & $2.27^{\mathrm{d}}$ & $1.93^{\mathrm{e}}$ & $1.82^{\mathrm{e}}$ \\
\hline Cultivated land (Rice) & $2.53^{\mathrm{c}}$ & $2.17^{\mathrm{d}}$ & $2.06^{\mathrm{d}}$ \\
\hline Cultivated land (Rice-potato) & $4.44^{\mathrm{a}}$ & $3.88^{\mathrm{a}}$ & $2.65^{\mathrm{a}}$ \\
\hline Fallow land & $2.61^{\mathrm{c}}$ & $2.31^{\mathrm{d}}$ & $1.99^{\mathrm{d}}$ \\
\hline$S E(m)$ & 0.07 & 0.06 & 0.04 \\
\hline$S E(D)$ & 0.10 & 0.09 & 0.06 \\
\hline$L S D(0.05)$ & 0.22 & 0.19 & 0.12 \\
\hline p-value & $0.000 * *$ & $0.000 * *$ & $0.000 * *$ \\
\hline \multicolumn{4}{|c|}{$\begin{array}{l}\text { Mean value within the same column follow by same letter are not significantly differen } \\
\text { from each other at } \mathbf{p}<0.05 ; * \text { Significant at } \mathrm{P} \leq 0.05 ; * * \text { Significant at } \mathrm{P} \leq 0.01 \text {, NS nol } \\
\text { significant }\end{array}$} \\
\hline \multicolumn{4}{|c|}{ Main effects of soil depth (irrespective of land use types) on pHDA } \\
\hline Mean pHDA & $2.91^{\mathrm{a}}$ & $2.47^{\mathrm{b}}$ & $2.07^{c}$ \\
\hline$S E(m)$ & \multicolumn{3}{|c|}{0.024} \\
\hline$S E(D)$ & \multicolumn{3}{|c|}{0.035} \\
\hline$L S D(0.05)$ & \multicolumn{3}{|c|}{0.070} \\
\hline p-value & \multicolumn{3}{|c|}{$0.000 * *$} \\
\hline
\end{tabular}

Table.3 Interaction effects of land use types and depth of soil on $\mathrm{pH}$ dependent acidity (pHDA)

\begin{tabular}{|c|c|c|c|}
\hline \multirow[t]{2}{*}{ Land use types } & \multicolumn{3}{|c|}{ pHDA $\left[\mathrm{cmol}\left(\mathrm{p}^{+}\right) \mathrm{kg}^{-1}\right]$ at various soil depth } \\
\hline & $0-20 \mathrm{~cm}$ & $20-40 \mathrm{~cm}$ & $40-60 \mathrm{~cm}$ \\
\hline Forest land & $3.36^{\mathrm{c}}$ & $2.86^{\mathrm{d}}$ & $2.40^{\mathrm{f}}$ \\
\hline Orchard land & $3.24^{\mathrm{c}}$ & $2.51^{\mathrm{ef}}$ & $2.20^{\mathrm{g}}$ \\
\hline Pasture land & $2.27^{\mathrm{fg}}$ & $1.93^{\mathrm{h}}$ & $1.82^{\mathrm{h}}$ \\
\hline Cultivated land (Rice) & $2.53^{\text {ef }}$ & $2.17^{\mathrm{g}}$ & $2.06^{\mathrm{gh}}$ \\
\hline Cultivated land (Rice-Potato) & $4.44^{\mathrm{a}}$ & $3.88^{\mathrm{b}}$ & $2.65^{\mathrm{e}}$ \\
\hline Fallow land & $2.61^{\mathrm{e}}$ & $2.31^{\mathrm{fg}}$ & $1.99^{\mathrm{h}}$ \\
\hline$S E(m)$ & \multicolumn{3}{|c|}{0.060} \\
\hline$S E(D)$ & \multicolumn{3}{|c|}{0.085} \\
\hline$L S D(0.05)$ & \multicolumn{3}{|c|}{0.172} \\
\hline p-value & \multicolumn{3}{|c|}{$0.000 * *$} \\
\hline
\end{tabular}


Table.4 Depth-wise variations in mean total potential acidity (TPA) of soil of different land use types and main effects of land use types (irrespective of depth) on TPA

\begin{tabular}{|c|c|c|c|c|c|c|}
\hline \multirow[t]{2}{*}{ Depth of soil } & \multicolumn{6}{|c|}{ TPA $\left[\mathrm{cmol}\left(\mathrm{p}^{+}\right) \mathrm{kg}^{-1}\right]$ of soil at various land use types } \\
\hline & Forest land & $\begin{array}{l}\text { Orchard } \\
\text { land }\end{array}$ & $\begin{array}{l}\text { Pasture } \\
\text { land }\end{array}$ & $\begin{array}{l}\text { Cultivated } \\
\text { land (Rice) }\end{array}$ & $\begin{array}{l}\text { Cultivated land } \\
\text { (Rice-potato) }\end{array}$ & Fallow land \\
\hline \multicolumn{7}{|c|}{ Depth-wise variations in mean TPAof soil of different land use types } \\
\hline $0-20 \mathrm{~cm}$ & $3.78^{\mathrm{a}}$ & $3.66^{\mathrm{a}}$ & $2.55^{\mathrm{a}}$ & $2.87^{\mathrm{a}}$ & $5.02^{\mathrm{a}}$ & $2.98^{\mathrm{a}}$ \\
\hline $20-40 \mathrm{~cm}$ & $3.22^{\mathrm{b}}$ & $2.83^{\mathrm{b}}$ & $2.18^{\mathrm{b}}$ & $2.44^{\mathrm{b}}$ & $4.33^{\mathrm{b}}$ & $2.59^{\mathrm{b}}$ \\
\hline $40-60 \mathrm{~cm}$ & $2.71^{\mathrm{c}}$ & $2.47^{\mathrm{c}}$ & $2.05^{\mathrm{c}}$ & $2.29^{\mathrm{b}}$ & $2.98^{c}$ & $2.18^{\mathrm{c}}$ \\
\hline$S E(m)$ & 0.05 & 0.06 & 0.02 & 0.05 & 0.10 & 0.05 \\
\hline$S E(D)$ & 0.07 & 0.09 & 0.03 & 0.07 & 0.15 & 0.07 \\
\hline$L S D(0.05)$ & 0.18 & 0.22 & 0.07 & 0.16 & 0.36 & 0.17 \\
\hline p-value & $0.000 * *$ & $0.000 * *$ & $0.000^{* *}$ & $0.000 * *$ & $0.000 * *$ & $0.000 * *$ \\
\hline \multicolumn{7}{|c|}{$\begin{array}{l}\text { Mean value within the same column follow by same letter are not significantly different from each other at } \\
p<0.05 ; * \text { Significant at } P \leq 0.05 ; * \text { Significant at } P \leq \mathbf{0 . 0 1} \text {, NS non significant }\end{array}$} \\
\hline \multicolumn{7}{|c|}{ Main effects of land use types (irrespective of depth) on TPA of soil } \\
\hline Mean TPA & $3.24^{\mathrm{b}}$ & $2.99^{c}$ & $2.26^{\mathrm{e}}$ & $2.53^{\mathrm{d}}$ & $4.11^{\mathrm{a}}$ & $2.58^{\mathrm{d}}$ \\
\hline$S E(m)$ & \multicolumn{6}{|c|}{0.035} \\
\hline$S E(D)$ & \multicolumn{6}{|c|}{0.050} \\
\hline$L S D(0.05)$ & \multicolumn{6}{|c|}{0.101} \\
\hline p-value & \multicolumn{6}{|c|}{$0.000 * *$} \\
\hline
\end{tabular}

Table.5 Land use types-wise variations in mean total potential acidity (TPA) of soil in different depth and main effects of depth of soil (irrespective of land use types) on TPA

\begin{tabular}{|c|c|c|c|}
\hline \multirow[t]{2}{*}{ Land use types } & \multicolumn{3}{|c|}{ TPA $\left[\mathrm{cmol}\left(\mathrm{p}^{+}\right) \mathrm{kg}^{-1}\right]$ at various soil depth } \\
\hline & $0-20 \mathrm{~cm}$ & $20-40 \mathrm{~cm}$ & $40-60 \mathrm{~cm}$ \\
\hline \multicolumn{4}{|c|}{ Land use-wise variations in mean TPA of soil in different depth } \\
\hline Forest land & $3.78^{\mathrm{b}}$ & $3.22^{\mathrm{b}}$ & $2.71^{\mathrm{b}}$ \\
\hline Orchard land & $3.66^{\mathrm{b}}$ & $2.83^{\mathrm{c}}$ & $2.47^{\mathrm{c}}$ \\
\hline Pasture land & $2.55^{\mathrm{d}}$ & $2.18^{\mathrm{e}}$ & $2.05^{\mathrm{e}}$ \\
\hline Cultivated land (Rice) & $2.87^{\mathrm{c}}$ & $2.44^{\mathrm{d}}$ & $2.29^{\mathrm{d}}$ \\
\hline Cultivated land (Rice-potato) & $5.02^{\mathrm{a}}$ & $4.33^{\mathrm{a}}$ & $2.98^{\mathrm{a}}$ \\
\hline Fallow land & $2.98^{\mathrm{c}}$ & $2.59^{\mathrm{d}}$ & $2.18^{\mathrm{d}}$ \\
\hline$S E(m)$ & 0.07 & 0.06 & 0.04 \\
\hline$S E(D)$ & 0.11 & 0.09 & 0.06 \\
\hline$L S D(0.05)$ & 0.23 & 0.19 & 0.14 \\
\hline p-value & $0.000 * *$ & $0.001 * *$ & $0.000 * *$ \\
\hline \multicolumn{4}{|c|}{$\begin{array}{l}\text { Mean value within the same column follow by same letter are not significantly different from each other a } \\
p<0.05 \text {; * Significant at } P \leq 0.05 ; * * \text { Significant at } P \leq 0.01 \text {, NS non significant }\end{array}$} \\
\hline \multicolumn{4}{|c|}{ Main effects of depth of soil (irrespective of land use types) on TPA of soil } \\
\hline Mean TPA & $3.29^{\mathrm{a}}$ & $2.78^{b}$ & $2.32^{\mathrm{c}}$ \\
\hline$S E(m)$ & & 0.025 & \\
\hline$S E(D)$ & & 0.035 & \\
\hline$L S D(0.05)$ & & 0.072 & \\
\hline p-value & & $0.000^{* *}$ & \\
\hline
\end{tabular}


Table.6 Interaction effects of land use types and depth of soil on total potential acidity (TPA)

\begin{tabular}{|c|c|c|c|}
\hline \multirow[t]{2}{*}{ Land use types } & \multicolumn{3}{|c|}{ TPA $\left[\mathrm{cmol}\left(\mathrm{p}^{+}\right) \mathrm{kg}^{-1}\right]$ at various soil depth } \\
\hline & $0-20 \mathrm{~cm}$ & $20-40 \mathrm{~cm}$ & $40-60 \mathrm{~cm}$ \\
\hline Forest land & $3.78^{c}$ & $3.22^{\mathrm{d}}$ & $2.71^{\mathrm{f}}$ \\
\hline Orchard land & $3.66^{\mathrm{c}}$ & $2.83^{\mathrm{e}}$ & $2.47^{\mathrm{g}}$ \\
\hline Pasture land & $2.55^{\mathrm{fg}}$ & $2.18^{\mathrm{h}}$ & $2.05^{\mathrm{h}}$ \\
\hline Cultivated land (Rice) & $2.87^{\mathrm{ef}}$ & $2.44^{\mathrm{g}}$ & $2.29^{\mathrm{gh}}$ \\
\hline Cultivated land (Rice-Potato) & $5.02^{\mathrm{a}}$ & $4.33^{\mathrm{b}}$ & $2.98^{\mathrm{e}}$ \\
\hline Fallow land & $2.98^{\mathrm{e}}$ & $2.59^{\mathrm{fg}}$ & $2.18^{\mathrm{h}}$ \\
\hline$S E(m)$ & \multicolumn{3}{|c|}{0.061} \\
\hline$S E(D)$ & \multicolumn{3}{|c|}{0.087} \\
\hline$L S D(0.05)$ & \multicolumn{3}{|c|}{0.176} \\
\hline p-value & \multicolumn{3}{|c|}{$0.000 * *$} \\
\hline
\end{tabular}

Fig.1 Depth-wise variation in $\mathrm{pH}$ dependent acidity of soil in various land use types

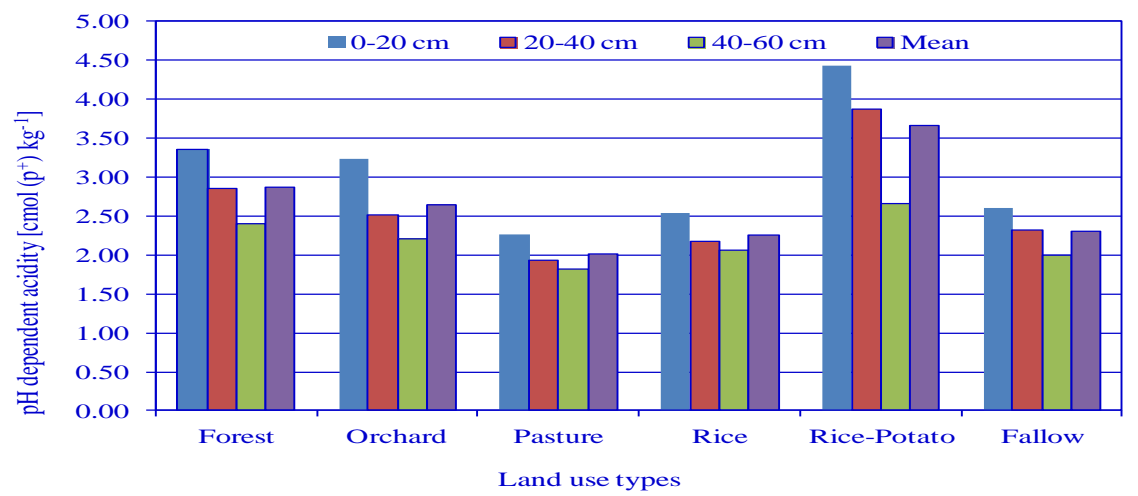

Fig.2 Land use type-wise variation in $\mathrm{pH}$ dependent acidity of soil in various soil depth

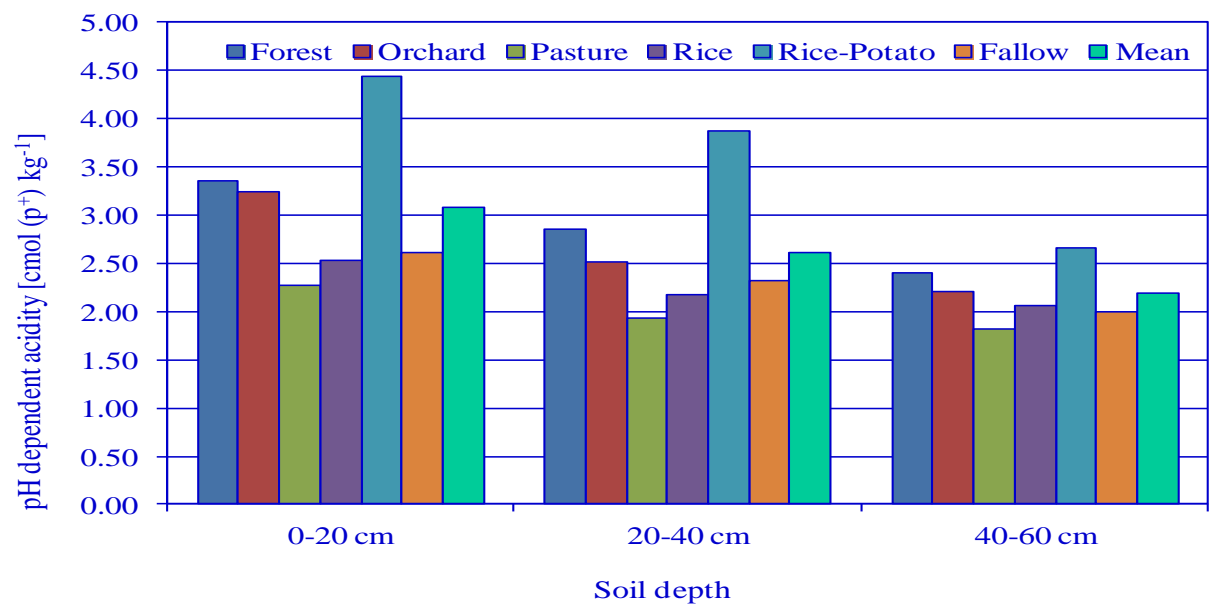


Fig.3 Depth-wise variation in total potential acidity of soil in various land use types

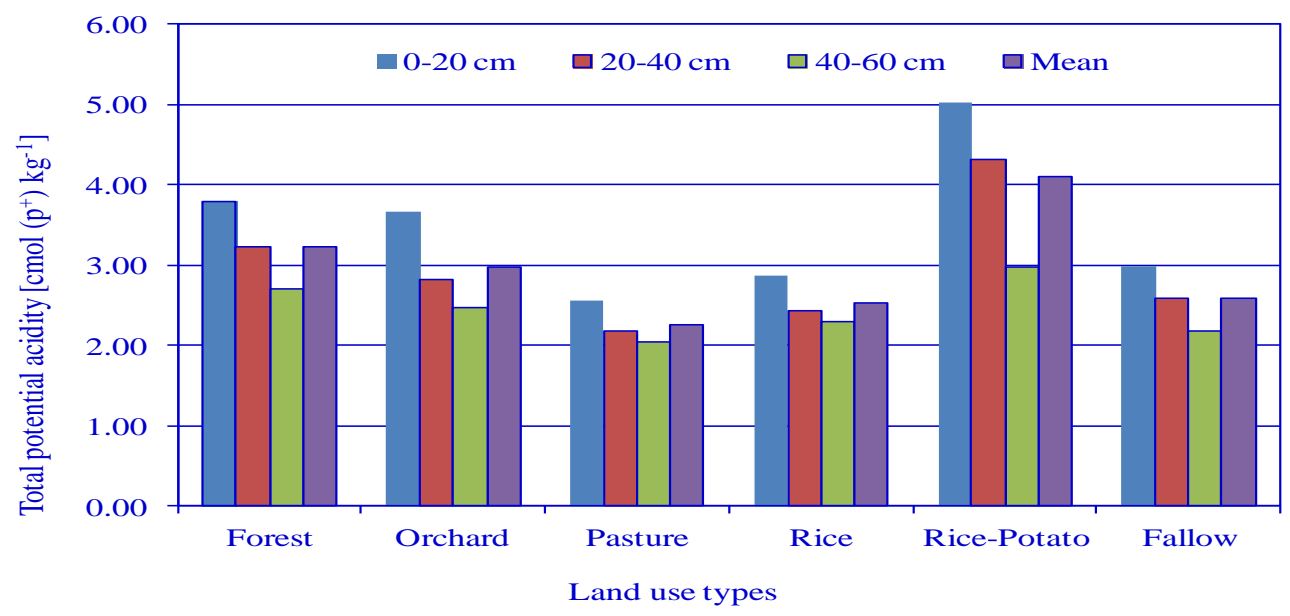

Fig.4 Land use type-wise variation in total potential acidity of soil in various soil depth

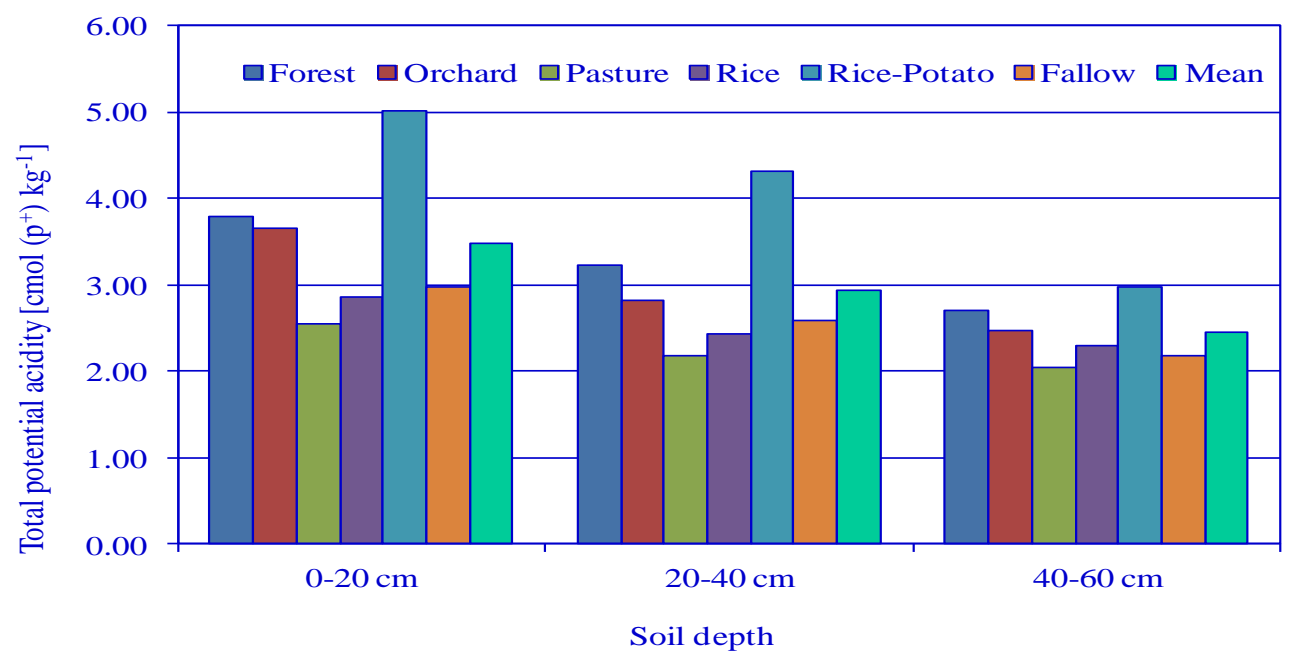

\section{References}

Badole, S., Datta, A., Basak, N., Seth, A., Padhan, D., and Mandal, B. 2015. Liming influences forms of acidity in soils belonging to different orders under subtropical India. Communications in Soil Science and Plant Analysis. 46: 2079-2094.

Bhat, J.A., Kundu, M.C., Hazra, G.C., Santra, G.H. and Mandal, B. 2010. Rehabilitating acid soils for increasing crop productivity through low-cost liming material. Science of the Total Environment. 408: 4346-53. doi:10.1016/j.scitotenv.2010.07.011. Black, C.A. 1965. Methods of soil analysis. Part 2, 771. Madison, Wisconsin: American Society of Agronomy.

Blake, G.R., and Hartge, K.H. 1986. Bulk density. In: Klute, A., Ed., Methods of soil analysis, Part 1-Physical and mineralogical methods, 2nd Edition, Agronomy Monograph 9, American Society of Agronomy-Soil Science Society of America, Madison. Pp. 
363-382.

Brady, N. C., and Weil, R.R. 2008. The nature and properties of soils, 14th ed., 980. Upper Saddle River, NJ: Pearson Education, Prentice- Hall Inc.

Bray, R., and Kurtz, L.T. 1945. Determination of total, organic, and available forms of phosphorus in soils. Soil Sci. 59(1): 39-46.

Dhananjaya, B.C. and Ananthanarayana, R. 2009. Soil acidity and exchange chemistry in soils of southern Karnataka. Agropedology. 19(2): 99105.

Gomez, K.A., and Gomez, A.A. 1984. Statistical Procedures for agricultural research. 2nd Edn., Int. Rice Res. Inst., John Willy and Sons, New York, Torento, Singapore. Pp. 643.

Hanway, J.J., and Heidel, H. 1952. Soil analysis methods as used in Iowa state college soil testing laboratory. Iowa Agriculture.

Jackson, M.L. 1973. Soil chemical analysis. Prentice Hall of India Pvt. Ltd., New Delhi. 498.

Kumar, K., Rao, K.V.P., and Singh, L. J. 1995. Forms of acidity in some acid inceptisols under different land use in Manipur. Journal of the Indian Society of Soil Science. 43: 338-342.

Kundu, M. C., Hazra, G. C., Mandal, B., and Bhat, J. A. 2017. Nature of acidity in alfisols, entisols and inceptisols in relation to soil properties. Communications in Soil Science and Plant Analysis. 48(4): 395-404.

Mandal, L. N., and Mandal, B. 1997. Acid soils of West Bengal - Their characteristics and management. In Acid soils of India, eds. Mahapatra, I.C., Mandal, S.C., Misra, C., Mitra, G.N., and Panda, N. 261-63. New Delhi, India: Indian Council Agric. Res.

Parfitt, R. L., Pervical, H. J., Dahlgren, H. A., and Hill, F. 1997. Soil and soil solution chemistry under pastures and radiatapine in New Zealand. Plant and Soil.91:279-290.

Peech, M., Cowan, R.L., and Baker, J.H. 1962. A critical study of the $\mathrm{BaCl}_{2-}$ Triethanolamine and the ammonium acetate methods for determining the exchangeable hydrogen content of soils. Soil Science Society of America Journal.26:37-40. doi:10.2136/ sssaj1962.03615995002600010010x.

Shivaprasad, C.R., Reddy, R.S., Sehgal, J., and Velayutham, M., 1998. Soils of Karnataka for optimizing land use, National Bureau of Soil Survey and Land Use Planning, Nagpur, publication 47, 15.

Subbiah, B.V., and Asija, G.L. 1956. A rapid Procedure for the estimation of available nitrogen in soils. Curr. Sci. 25(8): 259-260.

Walkley, A., Black, I.A. 1934. An Examination of the Degtjareff Method for Determining soil organic matter, and A proposed modification of the chromic acid titration method. Soil Sci. 37(1): 29-38.

\section{How to cite this article:}

Jhutan Debnath, Prodipto Sow and Manik Chandra Kundu. 2021. Variation of pH Dependent Acidity and Total Potential Acidity as Influenced by Land Uses and Soil Depths in Lateritic Belt of West Bengal. Int.J.Curr.Microbiol.App.Sci. 10(01): 1289-1298. doi: https://doi.org/10.20546/ijcmas.2021.1001.153 